\title{
Stomatal Functioning and Its Influence on Fruit Calcium Accumulation in Northern Highbush Blueberry
}

\author{
Fan-Hsuan Yang \\ Department of Horticulture, Oregon State University, Agricultural and Life \\ Science Building 4017, Corvallis, OR 97331 \\ Lisa W. DeVetter
Northwestern Washington Research and Extension Center, Washington State
University, 16650 State Route 536, Mount Vernon, WA 98273
}

Bernadine C. Strik

Department of Horticulture, Oregon State University, Agricultural and Life Science Building 4017, Corvallis, OR 97331

David R. Bryla

U.S. Department of Agriculture, Agricultural Research Service, Horticultural Crop Research Unit, 3420 NW Orchard Avenue, Corvallis, OR 97330

Additional index words. fruit quality, plant nutrition, stomatal conductance, Vaccinium corymbosum

\begin{abstract}
Accumulation of calcium (Ca) in fruit is largely caused by transpiration and varies depending on the concentration of $\mathrm{Ca}$ in the xylem fluid. The objective of the present study was to evaluate the relationship between fruit stomatal functioning and $\mathrm{Ca}$ accumulation during different stages of development in northern highbush blueberry (Vaccinium corymbosum L.). Stomata were scarce on the berries and were concentrated primarily on the distal end near the calyx. The density of the stomata was greatest at petal fall, averaging 5 to 108 stomata/mm $/ \mathrm{mm}^{2}$ from the proximal end (pedicel end) to the distal end of the berries. Stomata were wide-open at the early green stage of berry development and had a slight deposit of wax along the guard cells. As the berries expanded during the initial period of rapid growth (stage I), most of the stomata remained near the distal segment of the berries; by the late green stage, almost none was found in the middle and proximal segments. The majority of these stomata were completely covered with wax when the berries began to change color and ripen (stage II and stage III). Stomatal conductance ( $\left.g_{S}\right)$ of the berries averaged 45 $\mathrm{mmol} \cdot \mathrm{m}^{-2} \cdot \mathrm{s}^{-1}$ at petal fall and rapidly declined as the fruit developed. By the fruit coloring stage, conductance was low and remained less than $15 \mathrm{mmol} \cdot \mathrm{m}^{-2} \cdot \mathrm{s}^{-1}$ throughout the ripening period. In four cultivars, including Duke, Bluecrop, Aurora, and Elliott, Ca uptake in the berries increased rapidly during the early green stage; however, it slowed considerably between the late green and fruit coloring stages and stopped completely during fruit ripening. The results of this study strongly suggested that practices used to increase the Ca content of blueberries, such as the application of foliar fertilizers, should be performed early in the season during the first few weeks after flowering.
\end{abstract}

Calcium $(\mathrm{Ca})$ is considered important for plant health and fruit quality. Without a sufficient level of $\mathrm{Ca}$, several fruit quality defects may occur during fruit development (de Freitas and Mitcham, 2012). For example, multiple studies have concluded that insufficient $\mathrm{Ca}$ or an imbalance of $\mathrm{Ca}$ with other nutrients $(\mathrm{P}, \mathrm{Mg}, \mathrm{K}$, etc.) can cause bitter pit disorder in apple [Malus $\times$ sylvestris (L.) Mill. var. domestica (Borkh.) Mansf.] (de Freitas et al., 2015; Ferguson and Watkins, 1989). Calcium deficiency also leads to blossom-end rot in tomato (Solanum lycopersicum L.) (Ho and White, 2005) and fruit cracking in litchi (Litchi chinensis Sonn.) (Huang et al., 2008).

Fruit firmness is commonly associated with the level of $\mathrm{Ca}$ in the fruit. Studies have shown that $60 \%$ to $70 \%$ of $\mathrm{Ca}$ is located in the cell bloom, increased fruit $\mathrm{Ca}$ concentration and decreased fruit drop in 'Draper' blueberry. However, Arrington and DeVetter (2017) found that spraying various $\mathrm{Ca}$ products had no effect on firmness or fruit $\mathrm{Ca}$ content in two cultivars of blueberries grown at different locations in northwest Washington. Vance et al. (2017) reported similar results in Oregon and suggested that further research of fruit stomatal functionality was needed to identify the proper timing for $\mathrm{Ca}$ applications.

Studies of a number of crops, including grape, kiwifruit [Actinidia deliciosa (A. Chev) C.F. Liang et A.R. Ferguson var. deliciosa], and tomato, have suggested that Ca primarily accumulates during early stages of fruit development and decreases at later stages due to changes in xylem flow (Ho and White, 2005; Montanaro et al., 2015; Rogiers et al., 2006). Reduced xylem flow at later stages appears to be caused by the restriction of the xylem vessels during cellular expansion (Ho and White, 2005) and by reduced transpiration due to more wax on the fruit (Blanke and Leyhe, 1987, 1988; Rogiers et al., 2004). In blueberry, we found that wax thickens on the berries during development (Yang et al., 2019); however, whether it affects stomatal functionality and subsequent $\mathrm{Ca}$ accumulation is still unknown.

The objective of the present study was to evaluate the relationship between fruit stomatal functioning and $\mathrm{Ca}$ accumulation during different stages of development in northern highbush blueberry. This information is necessary to develop feasible practices for increasing $\mathrm{Ca}$ levels in the fruit.

\section{Materials and Methods}

\section{Study 1}

Study site. The study was conducted using mature plants of 'Elliott' blueberry located in a field with five other cultivars at the Oregon State University Lewis-Brown Horticultural

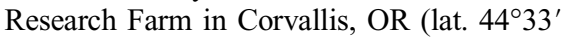
$\mathrm{N}$, long. $123^{\circ} 13^{\prime} \mathrm{W}$ ). 'Elliott' is a late-season cultivar that typically ripens in August and late September in western Oregon. The field was planted in Oct. 2008. Soil at the site was a Malabon silty clay loam (fine, mixed, superactive, mesic Pachic Ultic Argixerolls) with a $\mathrm{pH}$ of 5.5. The plants were spaced $0.8 \times 3.0 \mathrm{~m}$ apart on 0.4-m-high raised beds and were mulched every other year with a 5-cm-deep layer of douglas fir [Pseudotsuga menziesii Mirb. (Franco)] sawdust. Grass alleyways were planted between the beds and mowed as needed [see Vargas et al. (2015) for complete details regarding establishment of the planting].

Plants were irrigated using two lines of drip tubing (Netafim, Fresno, CA) per row and were fertigated weekly (from mid-April through July) with ammonium sulfate $(9 \mathrm{~N}-$ $0 \mathrm{P}-0 \mathrm{~K})$ at a total rate of $168 \mathrm{~kg} \cdot \mathrm{ha}^{-1} \mathrm{~N}$ per year. Urea, monoammonium phosphate, and boric acid were also applied in previous years (Vargas et al., 2015). The drip lines had integrated pressure-compensating emitters (2 $\mathrm{L} \cdot \mathrm{h}^{-1}$ ) every $0.45 \mathrm{~m}$ and were located $\approx 0.45 \mathrm{~m}$ from the base of the plants on each side of the row. Weeds were controlled, as needed, by 


\begin{tabular}{|c|c|c|c|}
\hline Stage of berry development ${ }^{z}$ & Description & Date & $\begin{array}{l}\text { No. of berries } \\
\text { per replicate }\end{array}$ \\
\hline 2. Early green & Pea-sized berry expanded by cell division and varied from small to large & 7 May & $55-75$ \\
\hline 3. Late green & $\begin{array}{l}\text { Berries slowed in growth and turned pale green; some exposed berries developed } \\
\text { a slight red blush }\end{array}$ & 30 June & $15-25$ \\
\hline 4. Fruit coloring & $\begin{array}{l}\text { The largest berry on the cluster began to soften and turn pink; growth occurred through } \\
\text { cell expansion }\end{array}$ & 8 July & $15-25$ \\
\hline 5. $10 \%$ blue & $\approx 10 \%$ of the berries, on a bush or in the field, were ripe and nearly ready for harvest & 15 July & $15-25$ \\
\hline
\end{tabular}

${ }^{\mathrm{z}}$ From Michigan State University Extension (http://www.canr.msu.edu/blueberries/growing_blueberries/growth-stages).
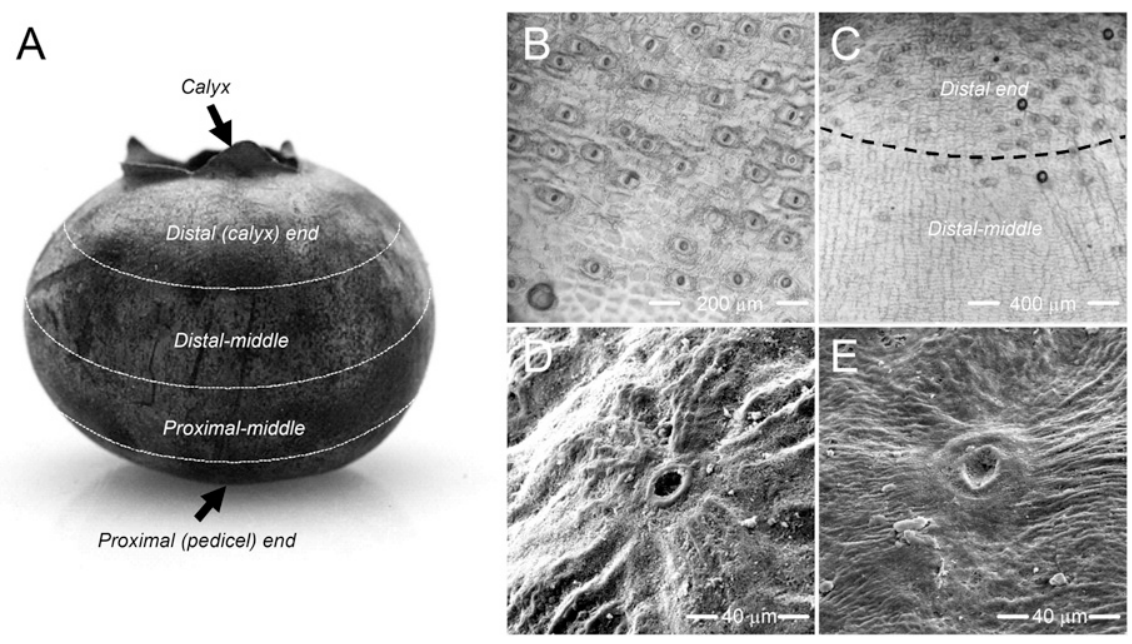

Fig. 1. (A) Illustration of the berry segments examined for stomata at different stages of development in 'Elliott' blueberry. Light microscopy: (B, C) stomata concentrated near the calyx at petal fall $(1800 \times$ and 1200x). Scanning electron microscopy: stomata on the surface of the berries during the (D) early green and (E) fruit coloring (pink) stages of berry development $(7200 \times)$.

hand-weeding on the top of beds and by applying glyphosate herbicide at the base of beds. No insecticides or fungicides were applied to the field during the study. Calcium fertilizer was never applied to the planting. Leaf tissue analysis (15 Aug. 2016) indicated that nutrients, including $\mathrm{Ca}$, were sufficient at the site and within the ranges recommended

Received for publication 13 Aug. 2019. Accepted for publication 28 Oct. 2019.

Published online 16 December 2019.

Funds for this research were provided by the Oregon and Washington Blueberry Commissions and the U.S. Department of Agriculture (CRIS number 2072-21000-048-00D). We thank Scott Orr, Suean Ott, Amanda Vance, and Sean Watkinson for technical assistance. We also thank Richard Sakuma for assisting with sampling. Mention of trademark, proprietary product, or vendor does not constitute a guarantee or warranty of the product by the U.S. Department of Agriculture and does not imply its approval of the exclusion of other products or vendors that also may be suitable.

F.-H.Y. is a former Ph.D. student. Current address: Sierra Cascade Nursery, 10230 Santa Fe Drive, Ballico, CA 95303.

D.R.B. is the corresponding author. E-mail: david.bryla@ usda.gov.

This is an open access article distributed under the CC BY-NC-ND license (https://creativecommons. org/licenses/by-nc-nd/4.0/). for northern highbush blueberry (Hart et al., 2006). The leaves were sampled and analyzed following the standard procedures for blueberry (Strik and Vance, 2015).

Berry dry weight and calcium content. Berry samples were collected at seven stages of fruit development: petal fall, early green, late green, fruit coloring, $10 \%$ blue, $25 \%$ blue, and $75 \%$ blue (Table 1 ). The percentage of blue was approximated and represented the proportion of berries that turned blue in the entire field on a given day. At each stage, berries were sampled from three individual plant replicates. The numbers of berries sampled at each stage of berry development are listed in Table 1. Samples were collected randomly from upper and lower parts of the canopy on both sides of the row. During the last stage ( $75 \%$ blue), additional samples (15 berries/replicate) were collected and separated into skin, pulp, and seeds to determine the distribution of dry matter and $\mathrm{Ca}$ in the berries. The berries and their components were digested using $70 \%(\mathrm{v} / \mathrm{v})$ nitric acid, as described by Gavlak et al., (2005), and then analyzed for $\mathrm{Ca}$ using an inductively coupled plasma (ICP) optical emission spectrometer (model Optima 3000DV; Perkin Elmer, Wellesley, MA). Other nutrients, including potassium $(\mathrm{K})$ and magnesium $(\mathrm{Mg})$, were also measured in the berries during the ICP analysis; nitrogen $(\mathrm{N})$ was measured using a combustion analyzer (model TruSpec CN; Leco Corp., St. Paul, MN).

Stomatal conductance. Stomatal conductance of the berries was measured on sunny days using a steady-state porometer (model LI1600; LI-COR, Lincoln, NE). Ten berries each were randomly measured from stage 1 through stage 6 (petal fall to $25 \%$ blue). Leaves were also measured on 10 plants at the late green stage (stage 3). For each measurement, a single berry was selected from a cluster, and the rest of the berries were removed before turning on the porometer. The porometer was equilibrated to site conditions for $30 \mathrm{~min}$ before each measurement, and the null point was set near ambient relative humidity. Each berry was clamped to the head of the porometer on the calyx side (i.e., facing the sensors). The aperture of the clamp was adjusted with different size openings on the foam pads $\left(0.35-0.90 \mathrm{~cm}^{2}\right)$, as needed, to accommodate different size berries. A complete seal and good contact between the instrument's thermocouple and the berry were ensured before starting the measurements. Each measurement required 5 to $10 \mathrm{~min}$ to obtain a stable reading.

Stomatal density and distribution. The number of stomata on the berries was counted using a light microscope (model DM 2500; Leica, Wetzlar, Germany). To prepare the samples, six berries each from stage 1 through stage 6 (Table 1) were randomly collected and coated with clear lacquer (nail polish). Leaf samples were also collected from plants at the late green stage and coated on the abaxial side with the lacquer. After drying, the lacquer was carefully peeled from the berries and leaves and placed on glass slides. For each berry sample, the berry was divided into the calyx and four equal spherical segments: the distal (calyx) end, distal-middle end, proximalmiddle end, and proximal (pedicel) end (Fig. 1A). Under the microscope, six photographs with an area of $1.65 \times 1.30 \mathrm{~mm}$ were randomly taken from each position at $1800 \times$ magnification. The stomata were then counted in the photographs and divided by the area to calculate the stomatal density on each segment of the berries. A total of 1080 photographs were processed. The results were analyzed by one-way analysis of variance (ANOVA) using R version 3.4.2 (R Core Team, 2017). Means were separated using Tukey's honestly significant difference test $(\alpha=0.05)$.

Stomata on the berries were also examined under a scanning electron microscope (SEM) 
Table 2. Berry sampling dates of 'Duke', 'Bluecrop', and 'Aurora' blueberry from fields located in Oregon and Washington in 2016 (study 2).

\begin{tabular}{|c|c|c|c|c|c|c|c|c|c|}
\hline \multirow[b]{2}{*}{ Stage of berry development $\mathrm{t}^{\mathrm{z}}$} & \multicolumn{3}{|c|}{ Corvallis, OR } & \multicolumn{3}{|c|}{ Aurora, OR } & \multicolumn{3}{|c|}{ Burlington, WA } \\
\hline & Duke & Bluecrop & Aurora & Duke & Bluecrop & Aurora & Duke & Bluecrop & $\overline{\text { Aurora }}$ \\
\hline 1. Petal fall & 23 Apr. & 25 Apr. & 27 Apr. & 26 Apr. & 26 Apr. & 26 Apr. & 2 May & 2 May & 3 May \\
\hline 2. Early green & 1 May & 1 May & 3 May & 2 May & 2 May & 2 May & 9 May & 9 May & 9 May \\
\hline 3. Late green & 19 May & 7 June & 30 June & 18 May & 31 May & 29 June & 24 June & 29 June & 26 June \\
\hline 4. Fruit coloring & 27 May & 10 June & 8 July & 26 May & 6 June & 5 July & 29 June & 29 June & 2 Aug. \\
\hline $5.10 \%$ blue & 7 June & 17 June & 15 July & 31 May & 15 June & 13 July & 5 July & 5 July & 2 Aug. \\
\hline 6. $25 \%$ blue & 10 June & 24 June & 20 July & 6 June & 24 June & 19 July & 5 July & 5 July & 19 Aug. \\
\hline 7. $75 \%$ blue & 16 June & 30 June & 27 July & 15 June & 29 June & 26 July & 5 July & 18 July & 19 Aug. \\
\hline
\end{tabular}

${ }^{\mathrm{z}}$ Berries in Corvallis and Aurora were selected based on the average stage of development in the field, whereas those in Burlington were selected based on development of individual plants. See Table 1 for a full description of the stages and the number of berries sampled at each stage.

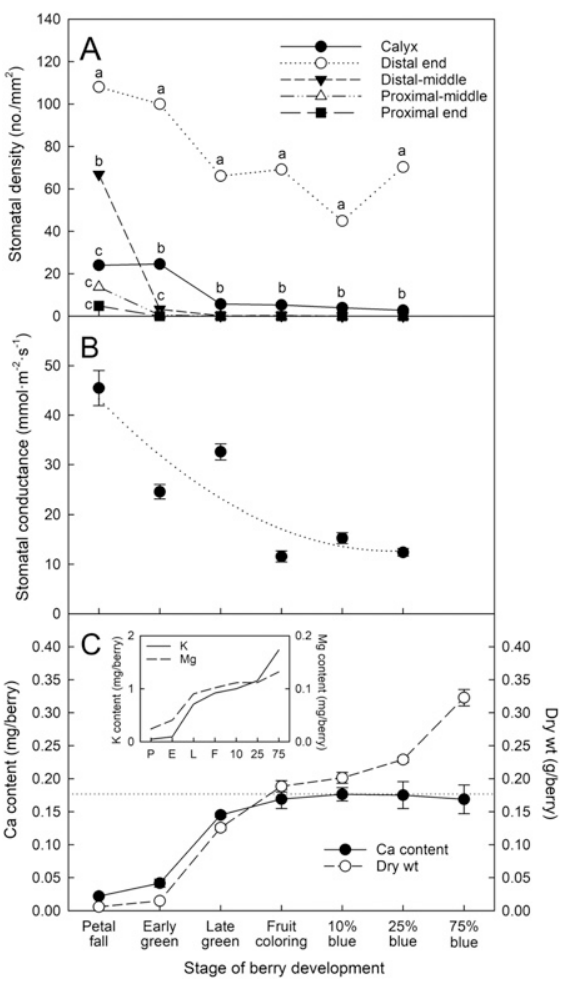

Fig. 2. (A) Stomatal density, (B) conductance, (C) $\mathrm{Ca}$ content, and dry weight of 'Elliott' blueberries from petal fall to the $75 \%$ blue stage of berry development (inset: $\mathrm{K}$ and $\mathrm{Mg}$ content in the berries). To assess stomatal density, berries were divided into the calyx and four equal spherical segments, including the distal (calyx) end, distal-middle end, proximal-middle end, and proximal (pedicel) end (see Fig. 1A). Means of stomatal density with different letters at a given stage were significantly different at $P \leq 0.05$. Error bars represent $\pm 1 \mathrm{SE}$.

(Quanta 600F; FEI Company, Hillsboro, OR) with an acceleration voltage of $10 \mathrm{kV}$. Eight berries from the sun-exposed part of the canopy were collected at three stages, including early green, fruit coloring, and $25 \%$ blue. To avoid removing the wax during sampling, each berry was held by inserting a dissection needle through the distal (calyx) end. Skin (epidermis) was carefully removed from the equator of each berry using a razor blade. The skin was immediately submerged into a fixation solution $(2.5 \%$ glutaraldehyde and $1 \%$ paraformaldehyde in $0.1 \mathrm{M}$ sodium cacodylate buffer) and stored overnight at $5{ }^{\circ} \mathrm{C}$. Very little fruit pulp was retained on the skin during removal, and most of it separated from the skin after fixation. Approximately $20 \mathrm{~h}$ later, skin samples were gradually washed with a series of $30 \%, 50 \%, 70 \%, 90 \%$, and $100 \%$ acetone; to maintain cellular structure, they were dehydrated using a $\mathrm{CO}_{2}$ critical point dryer (EMS 850; Electron Microscopy Sciences, Hatfield, PA). Once dried, the samples were frozen with liquid $\mathrm{N}$ and shattered into small specimens that were mounted on aluminum stubs with double-sided carbon tape and coated with a 15-nm-thick layer of $60 \%$ gold and $40 \%$ palladium (Cressington 108 Auto Sputter Coater; Cressington, Watford, UK). Images of the specimens were captured at a magnification of $7200 \times$.

\section{Study 2}

Additional berry samples were collected from three cultivars of northern highbush blueberry at three sites in northwestern United States in 2016. The cultivars included: an early season cultivar, Duke, which ripens in late June and July; a midseason cultivar, Bluecrop, which ripens in July and early August; and a late-season cultivar, Aurora, which ripens in August and early September. These cultivars represent more than $70 \%$ of the total planted area in the region. The sites included the field at Lewis-Brown in Corvallis (see study 1), a certified organic field located at the North Willamette Research and Extension Center in Aurora, OR (lat. $45^{\circ} 28^{\prime} \mathrm{N}$, long. $122^{\circ} 76^{\prime} \mathrm{W}$ ), and three conventional fields located at a commercial farm (Sakuma Bros.) in Burlington, WA (lat. $48^{\circ} 30^{\prime} \mathrm{N}$, long. $122^{\circ} 22^{\prime} \mathrm{W}$ ). Plants at each location were drip-irrigated (one or two lines per row) and fertigated or fertilized with ammonium sulfate, urea, or organic fertilizers (organic planting), including a soluble grain fermentation and sodium nitrate blend $(4 \mathrm{~N}-0.9 \mathrm{P}-0.4 \mathrm{~K}$; Converted Organics of California, Gonzales, CA), a fish hydrolysate and fish emulsion blend combined with molasses $(5 \mathrm{~N}-0.4 \mathrm{P}-1.6 \mathrm{~K}$; True Organic Products, Spreckels, CA), and a granular soybean meal ( $7 \mathrm{~N}-0.4 \mathrm{P}-1.6 \mathrm{~K}$; California Organic Fertilizers, Fresno, CA). Calcium sulfate (gypsum) was also applied to the organic planting at a rate of $258 \mathrm{~kg} \cdot \mathrm{ha}^{-1} \mathrm{Ca}$ in 2013 [see Strik et al. (2017b) for more information regarding the organic site]. A standard analysis of the leaves (15-19 Aug. 2016) indicated that most nutrients, including $\mathrm{Ca}$, were sufficient at each site and within the range recommended for northern highbush blueberry; however, boron (B) was below normal in 'Aurora' blueberry at the site in Corvallis,
OR (21 ppm B) (Hart et al., 2006; Strik and Vance, 2015).

Berries from each cultivar were sampled at the same seven stages of development as 'Elliott' (study 1), but the actual date on which the berries were collected varied among the locations and cultivars (Table 2). A set of berries was sampled from three individual plant replicates at each site. The berries were collected from the same plants at each developmental stage at the two sites in Oregon, and from different plants (within three replicated plots of six plants each) for each stage of development at the site in Washington. Each sample was washed, weighed, and analyzed for $\mathrm{Ca}$ and other nutrients, as described (study 1). An additional 15 berries were collected at the $75 \%$ blue stage to assess the distribution of dry matter and $\mathrm{Ca}$ in the skin, pulp, and seeds. The data were analyzed using an ANOVA and R software v. 3.1.2.

\section{Results}

Stomatal density and distribution. Stomata were scarce on the berries and concentrated primarily on the distal end near the calyx (Fig. 1B and C). Density of the stomata was greatest at petal fall, averaging 5 to 108 stomata/ $\mathrm{mm}^{2}$ from the distal end to the proximal end of the berries (Fig. 2A). In comparison, the mean density on the abaxial surface of the leaves was, on average, 496 stomata $/ \mathrm{mm}^{2}$. Stomata were wide-open at the early green stage of berry development and had only a slight deposit of wax along the guard cells (Fig. 1D).

As the berries expanded during the initial period of rapid growth (stage I), most of the stomata remained near the distal end of the berries, and by the late green stage, almost none was found in the middle and proximal segments (Fig. 2A). The majority of these stomata were completely covered with wax when the berries began to change color and ripen (stages II and III; Fig. 1E). By the time the berries were blue, it was nearly impossible to locate the stomata with the SEM.

Stomatal conductance. Stomatal conductance of the berries averaged $45 \mathrm{mmol} \cdot \mathrm{m}^{-2} \cdot \mathrm{s}^{-1}$ at petal fall and rapidly declined as the fruit developed (Fig. 2B). By the fruit coloring stage, conductance was low and remained less than $15 \mathrm{mmol} \cdot \mathrm{m}^{-2} \cdot \mathrm{s}^{-1}$ throughout the ripening period. Leaf $g_{\mathrm{S}}$ measured at the green stage averaged $\approx 100 \mathrm{mmol} \cdot \mathrm{m}^{-2} \cdot \mathrm{s}^{-1}$.

Accumulation and partitioning of dry matter and calcium. With 'Elliott', dry 


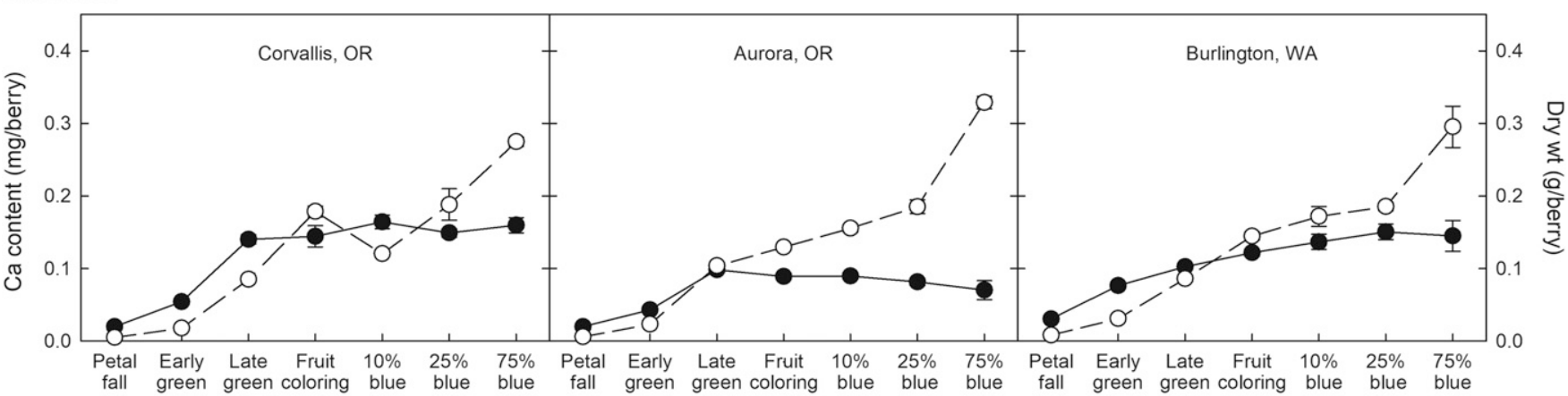

B. Bluecrop

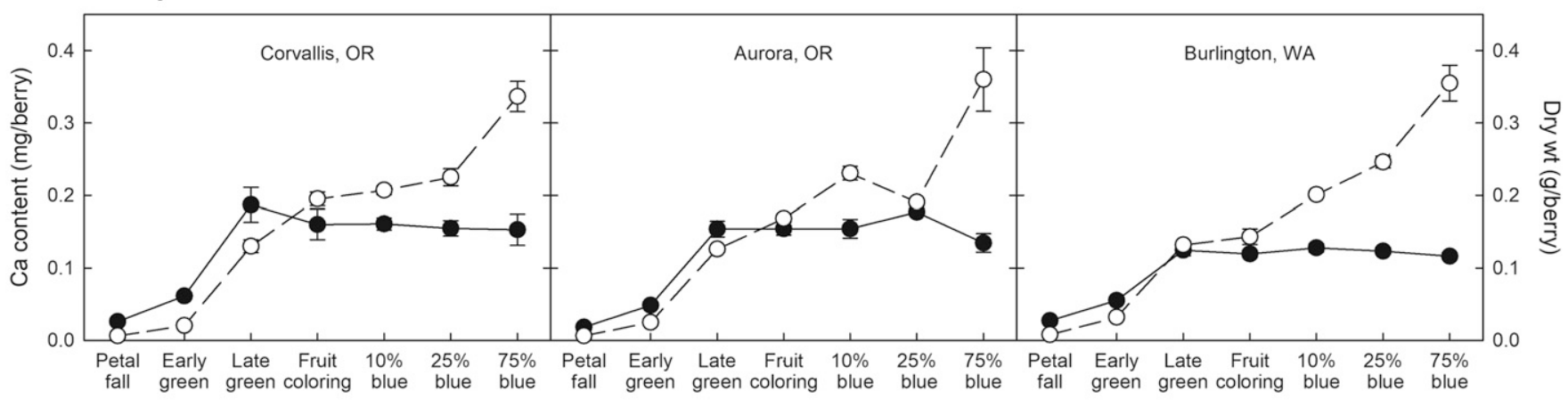

\section{Aurora}

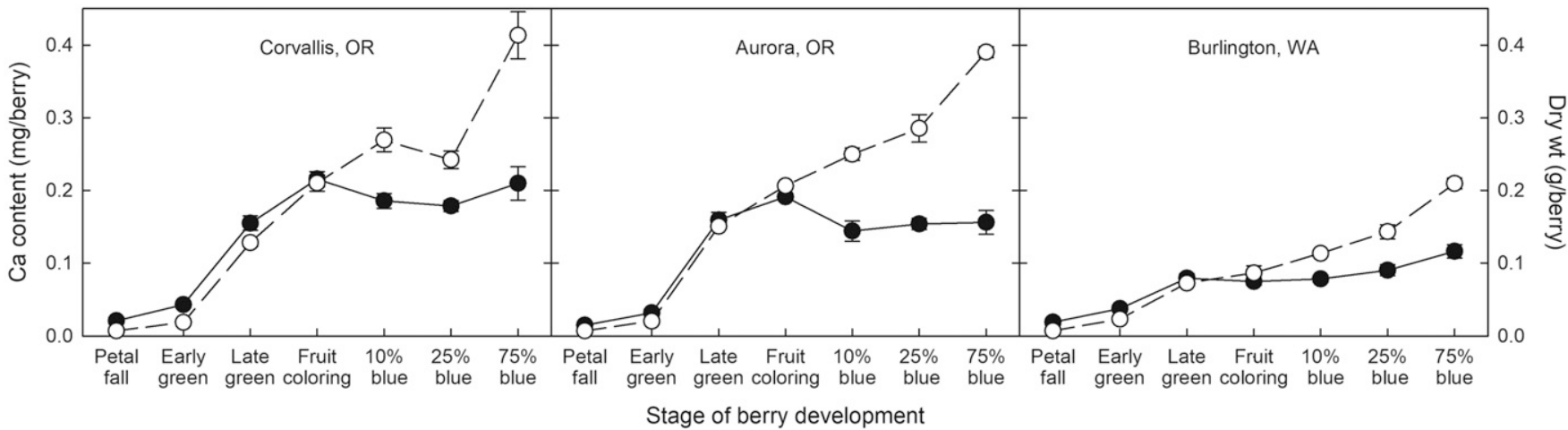

Fig. 3. Calcium content and dry weight of (A) 'Duke', (B) 'Bluecrop', and (C) 'Aurora' blueberries from petal fall to the 75\% blue stage of berry development. Berries were collected in 2016 from sites located (from south to north) in Corvallis, OR, Aurora, OR, and Burlington, WA. The sites in Corvallis and Burlington were managed conventionally, whereas the site in Aurora was certified organic. Error bars represent \pm 1 SE.

matter accumulated in the berries in a typical double-sigmoid pattern, with an initial period of rapid growth (stage I) from petal fall to fruit coloring, followed by a short lag period of growth (stage II) during fruit coloring, and, finally, a second period of rapid growth (stage III) during fruit ripening and before harvest (Fig. 2C). Calcium also accumulated rapidly during the initial stage of berry development; however, in this case, accumulation slowed considerably between the late green and fruit coloring stages, and it stopped completely during fruit ripening (Fig. 2C). In contrast, $\mathrm{K}$ and $\mathrm{Mg}$ continued to accumulate throughout development of the berries (Fig. 2C, inset).

Calcium accumulation also typically slowed or stopped by the late green stage in 'Duke', 'Bluecrop', and 'Aurora' (Fig. 3), whereas uptake of $\mathrm{K}, \mathrm{Mg}$, and other nutri- ents such as $\mathrm{N}$, phosphorus (P), and sulfur (S) continued throughout berry development in each cultivar (data not shown). Results of a three-way analysis indicated that the dry weight and $\mathrm{Ca}$ content of the berries were significantly affected by location, cultivar, and stage of development, as well as by two-way interactions of cultivar $x$ stage and location $\times$ stage $(P \leq 0.05)$. In general, $\mathrm{Ca}$ accumulation appeared to end sooner in the early and midseason cultivars (Duke and Bluecrop) than in the late-season cultivar (Aurora; also see Elliott) (Fig. 2C). However, there were two exceptions. In Burlington, WA, 'Duke' continued to accumulate $\mathrm{Ca}$ until the berries were $25 \%$ blue (Fig. 3A); however, 'Aurora' appeared to stop accumulating $\mathrm{Ca}$ by the late green stage but then resumed uptake once the berries were $25 \%$ blue (Fig. 3C).
By harvest $(25 \%$ and $75 \%$ blue stage of the field), the Ca content was less than 0.15 $\mathrm{mg} /$ berry, on average, in each of the cultivars examined. However, levels were low in two cultivars in Burlington, WA, averaging only 0.12 and $0.10 \mathrm{mg} /$ berry of $\mathrm{Ca}$ each in 'Bluecrop' and 'Aurora', respectively (Fig. 3B and C). 'Duke' also had low $\mathrm{Ca}$ in the berries at the organic site in Aurora, OR. Despite a large amount of dry matter $(0.33 \mathrm{mg} /$ berry $)$, 'Duke' berries from the organic site accumulated only $0.07 \mathrm{mg} /$ berry of $\mathrm{Ca}$ by the $75 \%$ blue stage, which was less than half the amount measured at the same stage in Corvallis and Burlington (Fig. 3A).

When the berries matured, $18 \%$ of the total dry matter in 'Elliott' berries was in the skin, $75 \%$ was in the pulp, and less than $7 \%$ was in the seeds (Table 3). Calcium, however, was approximately three-times more 
Table 3. Mean ( $( \pm \mathrm{SE})$ dry weight and concentration and content of Ca in the skin, pulp, and seeds of 'Elliott' blueberries $(\mathrm{n}=3)^{\mathrm{z}}$

\begin{tabular}{lccc}
\hline Berry component & Dry wt $(\mathrm{g} /$ berry) & Ca concn $(\%)$ & Ca content $(\mathrm{mg} /$ berry) \\
\hline Skin & $0.055 \pm 0.005$ & $0.099 \pm 0.002$ & $0.054 \pm 0.004$ \\
Pulp & $0.224 \pm 0.019$ & $0.036 \pm 0.002$ & $0.080 \pm 0.003$ \\
Seeds & $0.019 \pm 0.001$ & $0.112 \pm 0.006$ & $0.021 \pm 0.003$ \\
Total & $0.297 \pm 0.021$ & $0.052 \pm 0.002$ & $0.155 \pm 0.003$ \\
\hline
\end{tabular}

${ }^{\mathrm{z}}$ Measured at the $75 \%$ blue stage of berry development.

\section{Duke}
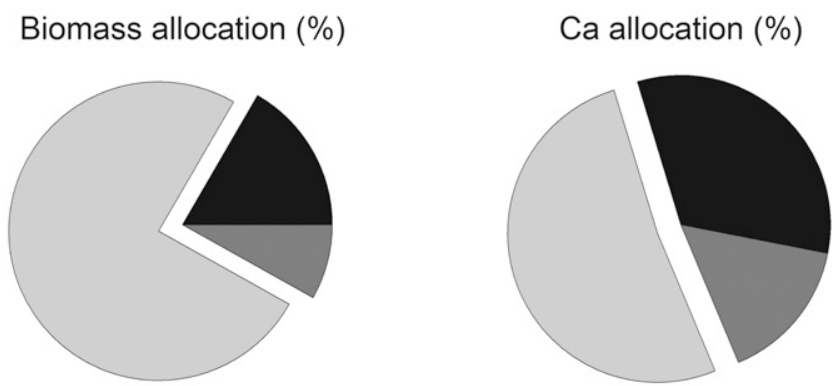

\section{Bluecrop}

Biomass allocation (\%)
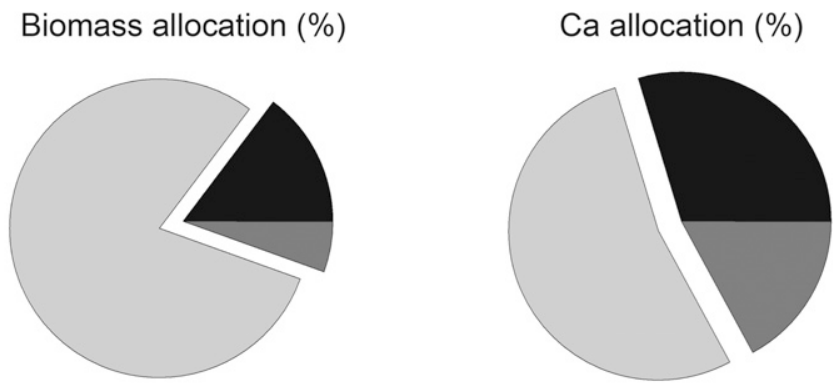

\section{Aurora}
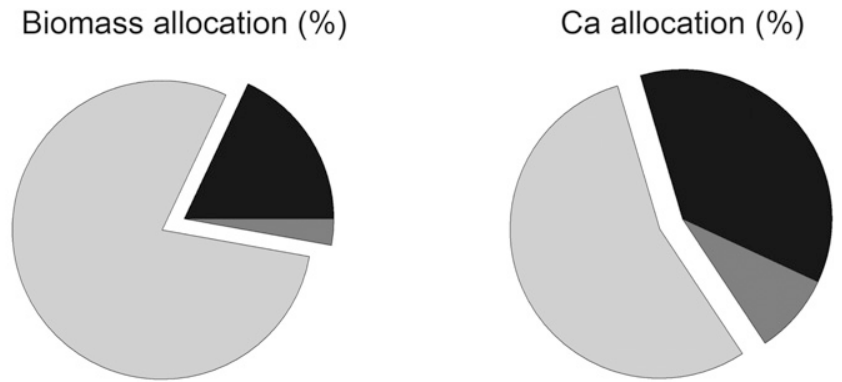

Fig. 4. Allocation of dry biomass and Ca among the skin, pulp, and seeds of 'Duke', 'Bluecrop', and 'Aurora' blueberries. Data are pooled from berries collected at the $75 \%$ blue stage of berry development in Corvallis, OR, Aurora, OR, and Burlington, WA $(\mathrm{n}=3)$.

concentrated in the skin and seeds than in the pulp; consequently, nearly half of the $\mathrm{Ca}$ in the berries was in the skin $(35 \%)$ and seeds (13\%) (Table 3). Proportionally less dry matter and more $\mathrm{Ca}$ were also allocated to the skin and seeds of 'Duke', 'Bluecrop', and 'Aurora' berries (Fig. 4). A two-way analysis revealed that allocation of dry matter and $\mathrm{Ca}$ to each tissue was affected by cultivar $(P \leq$ 0.01 ), but it was unaffected by the location in which the berries were collected or by the interaction of cultivar $\times$ location. In these cultivars, partitioning of dry matter and $\mathrm{Ca}$ were similar at each site, although 'Aurora' allocated significantly more dry matter and $\mathrm{Ca}$ to the skin and less to the seeds than either 'Duke' or 'Bluecrop'.

\section{Discussion}

The results of this study indicated that $\mathrm{Ca}$ accumulation occurs primarily during the early stages of fruit development in northern highbush blueberry and appears to be limited at later stages by reduced stomatal functioning and development of wax on the berry surface. Most of the $\mathrm{Ca}$ uptake occurred while the berries were small and green and actively transpiring during stage I. Calcium accumulates mainly during early fruit development in other crops, including apple, apri$\cot (P$. armeniaca L.), grape, kiwifruit, and nectarine $[P$. persica (L.) Batsch var. nucipersica (Suckow) C.K. Schneid.] (Creasy et al., 1993; Dichio et al., 2003; Drazeta et al., 2004; Montanaro et al., 2010, 2014). Unlike most nutrients in plants, the movement of $\mathrm{Ca}$ relies on xylem fluid driven by transpiration. Therefore, as water translocation switches from xylem to phloem during fruit development, $\mathrm{Ca}$ movement becomes limited (Hanger, 1979). When the xylem is no longer functional, any additional accumulation of $\mathrm{Ca}$ in the fruit is strongly reduced (Ho and White, 2005; Montanaro et al., 2015; Rogiers et al., 2006). In contrast, we found that uptake of other nutrients, including $\mathrm{K}$ and $\mathrm{Mg}$, continued to increase throughout each stage of development of the berries, including fruit coloring and ripening. Translocation of these nutrients to various organs occurs primarily via the phloem (Marschner, 2012).

Stomatal density of the blueberries declined as the fruit matured. Grusak and Pomper (1999) observed similar results in snap bean (Phaseolus vulgaris L.) pods. As in the present study, the decline in stomatal density was related to the expansive growth of the fruiting structures. It would appear that blueberries begin with a certain number of stomata that become more diffuse as the berries expand. During expansion, most of the stomata remained near the calyx or distal end of the berry. Eventually, these stomata became covered with wax and were probably no longer functional during the later stages of berry development. Therefore, by the time fruit coloring begins, water loss through the surface of the berries would have to occur via minute cracks in the cuticle (Konarska, 2015). Significant reduction in transpiration is also associated with thickening of epicuticular waxes after véraison in wine grape (Blanke and Leyhe, 1987, 1988; Rogiers et al., 2004).

The rate of $g_{S}$ measured in the berries after petal fall was approximately half of what was measured in actively transpiring leaves on the plants. Fruit stomata are wellknown as essential for gas exchange and $\mathrm{C}$ assimilation during early fruit development in many crops (Aschan and Pfanz, 2003; Cipollini and Levey, 1991; Palliotti and Cartechini, 2001). However, rates measured at later stages of development were comparable to leaves with closed stomata (Bryla and Strik, 2006). Cuticular water loss apparently predominates in the berries during later stages of development.

Among the cultivars examined in this study, Ca content was below average in 'Bluecrop' and 'Aurora' blueberries in Burlington, WA. These anomalies may have been because the berries in Washington were collected from different plants at each stage of development, whereas those in Oregon were sampled from the same plants at each stage. However, the Burlington site was the 
most northern of the sites sampled in the study, and the climate there is cooler and wetter than at the other two sites sampled in Oregon (Yang et al., 2019). Low temperatures and high humidity reduce vapor pressure deficit; therefore, they might have resulted in a reduction in the cumulative influx of $\mathrm{Ca}$ in the xylem sap at this site (Zhang and Keller, 2015). Seeds in the fruit are also involved in fruit $\mathrm{Ca}$ accumulation (Buccheri and Di Vaio, 2005). Cultivars that regularly produce low numbers of seeds or are exposed to poor environmental conditions during pollination are expected to have lower fruit Ca levels (Arrington and DeVetter, 2016). Weather conditions were poor during pollination in Washington in 2016 (L. DeVetter, personal observation), which could have reduced the number of seeds per berry and the associated accumulation of $\mathrm{Ca}$ in the fruit. In contrast, seed number was consistently high in Aurora, OR, due to the favorable climate and a high potential for cross-pollination among the cultivars at the site (Strik et al., 2017b; Strik and Vance, 2019).

The Ca content was also below average in organic 'Duke' blueberries. Many organic fertilizers, including those used in this study, tend to be high in $\mathrm{K}$ and low in $\mathrm{Ca}$. Yard debris compost, which is also high in $\mathrm{K}$, was also incorporated in the soil and used as a mulch in the planting (Strik et al., 2017b). Excessive $\mathrm{K}$ can inhibit Ca uptake in plants, thereby interfering with $\mathrm{Ca}$ movement to the leaves and fruit (Marschner, 2012). 'Duke', in particular, demonstrates a genetic tendency toward sensitivity to high $\mathrm{K}$ and any negative effects it might have on fruit and leaf Ca (Strik and Vance, 2015; Strik et al., 2017a, 2019).

Although $g_{\mathrm{S}}$ is low in developing blueberries, it appears to be an important mechanism by which $\mathrm{Ca}$ is delivered to the fruit. Therefore, to increase $\mathrm{Ca}$ and enhance the quality of the fruit, cultivars could be developed with more stomata on the berry surface. Less wax would also increase stomatal functioning, particularly at later stages of berry development, but it might lead to problems such as increased infection by fungi and bacteria, more physical damage, and higher rates of water loss after harvest (Jenks and Ashworth, 1999; Riederer and Schreiber, 2001). Alternatively, cultivars could be developed with a higher proportion of $\mathrm{Ca}$ in the skin of the berries, which, as mentioned, increases berry firmness and decreases cracking and postharvest decay of fruit in other crops. Cultural practices such as heavier pruning to increase light exposure or running fans to increase air circulation (e.g., for containerized production of blueberries in tunnels and greenhouses) could also be used as a more immediate means to improve xylem influx and movement of $\mathrm{Ca}$ into the berries (Mazzeo et al., 2011, 2013; Montanaro et al., 2006; Rebucci et al., 1997). Finally, applying soil or foliar $\mathrm{Ca}$ fertilizers during early stages of berry development can increase $\mathrm{Ca}$ in the berries
(Gerbrandt et al., 2019; Hanson and Berkheimer, 2004), but the efficacy of uptake may be limited by the rate of application, cultivar, and weather conditions (Arrington and DeVetter, 2017; Vance et al., 2017).

\section{Literature Cited}

Arrington, M. and L.W. DeVetter. 2016. Fruit set improvement of highbush blueberry (Vaccinium corymbosum): A review. J. Amer. Pomol. Soc. 70:124-137.

Arrington, M. and L.W. DeVetter. 2017. Foliar applications of calcium and boron do not increase fruit set or yield in northern highbush blueberry (Vaccinium corymbosum). HortScience 52:1259-1264.

Aschan, G. and H. Pfanz. 2003. Non-foliar photosynthesis - a strategy of additional carbon acquisition. Flora - Morphology Distribution Functional Ecol. Plants 198:81-97.

Blanke, M.M. and A. Leyhe. 1987. Stomatal activity of the grape berry cv. Riesling, Müller-Thurgau and Ehrenfelser. J. Plant Physiol. 127:451-460.

Blanke, M.M. and A. Leyhe. 1988. Stomatal and cuticular transpiration of the cap and berry of grape. J. Plant Physiol. 132:250-253.

Brown, G., S. Wilson, W. Boucher, B. Graham, and B. McGlasson. 1995. Effects of copper-calcium sprays on fruit cracking in sweet cherry (Prunus avium). Scientia Hort. 62:75-80.

Bryla, D.R. and B.C. Strik. 2006. Variation in plant and soil water relations among irrigated blueberry cultivars planted at two distinct in-row spacings. Acta Hort. 715:295-300.

Buccheri, M. and C. Di Vaio. 2005. Relationship among seed number, quality, and calcium content in apple fruits. J. Plant Nutr. 27:1735-1746.

Ciccarese, A., A.M. Stellacci, G. Gentilesco, and P. Rubino. 2013. Effectiveness of pre- and postveraison calcium applications to control decay and maintain table grape fruit quality during storage. Postharvest Biol. Technol. 75:135-141.

Cipollini, M.L. and D.J. Levey. 1991. Why some fruits are green when they are ripe: Carbon balance in fleshy fruits. Oecologia 88:371-377.

Creasy, G.L., S.F. Price, and P.B. Lombard. 1993. Evidence for xylem discontinuity in Pinot noir and Merlot grapes: Dye uptake and mineral composition during berry maturation. Amer. J. Enol. Viticult. 44:187-192.

de Freitas, S.T., C.V.T. do Amarante, and E.J. Mitcham. 2015. Mechanisms regulating apple cultivar susceptibility to bitter pit. Scientia Hort. 186:54-60.

de Freitas, S.T. and E.J. Mitcham. 2012. Factors involved in fruit calcium deficiency disorders. Hort. Rev. 40:107-146.

Demarty, M., C. Morvan, and M. Thellier. 1984. Calcium and the cell wall. Plant Cell Environ. 7:441-448

Dichio, B., D. Remorini, and S. Lang. 2003. Developmental changes in xylem functionality in kiwifruit fruit: Implications for fruit calcium accumulation. Acta Hort. 610:191-195.

Drazeta, L., A. Lang, A.J. Hall, R.K. Volz, and P.E. Jameson. 2004. Causes and effects of changes in xylem functionality in apple fruit. Ann. Bot. 93:275-282.

Dris, R. and R. Niskanen. 1999. Calcium chloride sprays decrease physiological disorders following long-term cold storage of apple. Plant Foods Hum. Nutr. 54:159-171.

Ferguson, I.B. and C.B. Watkins. 1989. Bitter pit in apple fruit. Hort. Rev. 11:289-355.

Gavlak, R.G., D.A. Horneck, and R.O. Miller. 2005. The soil, plant and water reference methods for the western region. 3rd ed. West- ern Regional Ext. Publ. 125. Univ. Alaska, Fairbanks, AK.

Gerbrandt, E.M., C. Mouritzen, and M. Sweeney. 2019. Foliar calcium corrects a deficiency causing green fruit drop in 'Draper' highbush blueberry (Vaccinium corymbosum L.). Agriculture 9:63. doi: 10.3390/agriculture9030063.

Grusak, M.A. and K.W. Pomper. 1999. Influence of pod stomatal density and pod transpiration on the calcium concentration of snap bean pods. J. Amer. Soc. Hort. Sci. 124:194-198.

Hanger, B.C. 1979. The movement of calcium in plants. Commun. Soil Sci. Plant Anal. 10:171-193.

Hanson, E.J. and S.F. Berkheimer. 2004. Effect of soil calcium applications on blueberry yield and quality. Small Fruits Rev. 3:133-139.

Hart, J., B. Strik, L. White, and W. Yang. 2006. Nutrient management for blueberries in Oregon. Oregon State University Extension Service. EM 8918. 2 Aug. 2019. <http://ir.library.oregonstate.edu/ xmlui/bitstream/handle/1957/20444/em8918.pdfs.

Ho, L.C. and P.J. White. 2005. A cellular hypothesis for the induction of blossom-end rot in tomato fruit. Ann. Bot. 95:571-581.

Huang, X.-M., H.-C. Wang, W.-L. Zhong, W.-Q. Yuan, J.-M. Lu, and J.-G. Li. 2008. Spraying calcium is not an effective way to increase structural calcium in litchi pericarp. Scientia Hort. 117:39-44.

Jenks, M.A. and E.N. Ashworth. 1999. Plant epicuticular waxes: Function, production, and genetics. Hort. Rev. 23:1-68.

Konarska, A. 2015. Morphological, anatomical, and ultrastructural changes in Vaccinium corymbosum fruits during ontogeny. Botany 93:589-602.

Lara, I., P. Garcì̀, and M. Vendrell. 2004. Modifications in cell wall composition after cold storage of calcium-treated strawberry (Fragaria $\times$ ananassa Duch.) fruit. Postharvest Biol. Technol. 34:331-339.

Marschner, P. (ed.). 2012. Marschner's mineral nutrition of higher plants, 3rd ed. Academic Press, New York.

Marzouk, H.A. and H.A. Kassem. 2011. Improving yield, quality, and shelf life of Thompson seedless grapevine by preharvest foliar applications. Scientia Hort. 130:425-430.

Mazzeo, M., B. Dichio, M.J. Clearwater, G. Montanaro, and C. Xiloyannis. 2013. Hydraulic resistance of developing Actinidia fruit. Ann. Bot. 112:197-205.

Mazzeo, M., B. Dichio, C. Xiloyannis, and A. Lang. 2011. Fruit transpiration increases with windspeed in Actinidia deliciosa 'Hayward'. Acta Hort. 913:385-388.

Montanaro, G., B. Dichio, A. Lang, A.N. Mininni, V. Nuzzo, M.J. Clearwater, and C. Xiloyannis. 2014. Internal versus external control of calcium nutrition in kiwifruit. J. Plant Nutr. Soil Sci. 177:819-830.

Montanaro, G., B. Dichio, A. Lang, A.N. Mininni, and C. Xiloyannis. 2015. Fruit calcium accumulation coupled and uncoupled from its transpiration in kiwifruit. J. Plant Physiol. 181:67-74.

Montanaro, G., B. Dichio, and C. Xiloyannis. 2010. Significance of fruit transpiration on calcium nutrition in developing apricot fruit. J. Plant Nutr. Soil Sci. 173:618-622.

Montanaro, G., B. Dichio, C. Xiloyannis, and G. Celano. 2006. Light influences transpiration and calcium accumulation in fruit of kiwifruit plants (Actinidia deliciosa var. deliciosa). Plant Sci. 170:520-527.

Palliotti, A. and A. Cartechini. 2001. Developmental changes in gas exchange activity in flowers, berries, and tendrils of field-grown Cabernet Sauvignon. Amer. J. Enol. Viticult. 52:317-323. 
R Core Team. 2017. R: A language and environment for statistical computing. R Foundation for Statistical Computing, Vienna, Austria. 2 Oct. 2017. <https://www.R-project.org>.

Rebucci, B., S. Poni, C. Intrieri, E. Magnanini, and A.N. Lakso. 1997. Effects of manipulated grape berry transpiration on post-veraison sugar accumulation. Austral. J. Grape Wine Res. 3:57-65.

Riederer, M. and L. Schreiber. 2001. Protecting against water loss: Analysis of the barrier properties of plant cuticles. J. Expt. Bot. 52:2023-2032.

Rogiers, S.Y., D.H. Greer, J.M. Hatfield, B.A. Orchard, and M. Keller. 2006. Mineral sinks within ripening grape berries (Vitis vinifera L.). Vitis 45:115-123.

Rogiers, S.Y., J.M. Hatfield, V.G. Jaudzems, R.G. White, and M. Keller. 2004. Grape berry cv. Shiraz epicuticular wax and transpiration during ripening and preharvest weight loss. Amer. J. Enol. Viticult. 55:121-127.

Siddiqui, S. and F. Bangerth. 1995. Effect of preharvest application of calcium on flesh firmness and cell-wall composition of apples - influence of fruit size. J. Hort. Sci. 70:263-269.

Strik, B.C. and A.J. Vance. 2015. Seasonal variation in leaf nutrient concentration of northern highbush blueberry cultivars grown in conventional and organic production systems. HortScience 50:1453-1466.

Strik, B.C. and A.J. Vance. 2019. Highbush blueberry cultivars differ in the relationship between seed number and berry weight during the harvest season. HortScience 54:1728-1736.

Strik, B.C., A. Vance, D.R. Bryla, and D.M. Sullivan. 2017a. Organic production systems in northern highbush blueberry. I. Impact of planting method, cultivar, fertilizer, and mulch on yield and fruit quality from planting through maturity. HortScience 52:1201-1213.

Strik, B.C., A. Vance, D.R. Bryla, and D.M. Sullivan. 2019. Organic production systems in northern highbush blueberry. II. Impact of planting method, cultivar, fertilizer, and mulch on leaf and soil nutrient concentrations and relationships with yield from planting through maturity. HortScience 54:1777-1794.
Strik, B.C., A. Vance, and C.E. Finn. 2017 b. Northern highbush blueberry cultivars differed in yield and fruit quality in two organic production systems from planting to maturity. HortScience 52:844-851.

Vance, A.J., P. Jones, and B.C. Strik. 2017. Foliar calcium applications do not improve quality or shelf life of strawberry, raspberry, blackberry, or blueberry fruit. HortScience 52:382-387.

Vargas, O.L., D.R. Bryla, J.E. Weiland, B.C. Strik, and L. Sun. 2015. Irrigation and fertigation with drip and alternative micro irrigation systems in northern highbush blueberry. HortScience 50:897-903.

Yang, F.-H., D.R. Bryla, and B.C. Strik. 2019. Critical temperatures and heating times for fruit damage in northern highbush blueberry. HortScience (In press).

Zhang, Y. and M. Keller. 2015. Grape berry transpiration is determined by vapor pressure deficit, cuticular conductance, and berry size. Amer. J. Enol. Viticult. 66:454-462. 